\title{
The MG Rover Closure and Policy Response: An evaluation of the Task Force Model in the UK
}

\section{Gill Bentley*, David Bailey and Alex De Ruyter}

\author{
Gill Bentley \\ Lecturer in Urban and Regional Economic Development \\ Centre for Urban and Regional Studies \\ Birmingham Business School \\ University of Birmingham \\ Edgbaston \\ Birmingham, \\ B15 2TT \\ g.a.bentley@bham.ac.uk
}

\section{David Bailey}

Professor of International Business Strategy and Economics

Coventry University Business School

Coventry University

Priory Street

Coventry

CV1 5FB

David.Bailey@coventry.ac.uk

\author{
Alex de Ruyter \\ Professor of Public Sector Management \\ University of the West of Scotland Business School \\ University of the West of Scotland \\ Paisley, \\ Scotland \\ PA1 2BE \\ Alex.deruyter@uws.ac.uk \\ * Corresponding author
}

\begin{abstract}
In recent years there have been a number of high-profile plant closures in the UK. . In several cases, the policy response has included setting up a task force to deal with the impacts of the closure. It can be hypothesised a that task force involving multi-level working across territorial boundaries and tiers of government is crucial to devising a policy response tailored to people's needs and to ensuring success in dealing with the immediate impacts of a closure. This suggests that leadership, and vision, partnership working and community engagement, and delivery of high quality services are important. This paper looks at the case of the MG Rover closure in 2005, to examine the extent to which the policy response to the closure at the national, regional and local levels dealt effectively with the immediate impacts of the closure, and the lessons that can be learned from the experience. Such lessons are of particular relevance given the closure of the LDV van plant in Birmingham in 2009 and more
\end{abstract}


broadly - such as in the case of the downsizing of the Opel operation in Europe following its takeover by Magna.

Key words: plant closures; retrenchment; automotive industry; job loss; redundancy; policy response; Task Force; governance; MG Rover.

Reference to this paper should be made as follows: Bentley, G., Bailey, D. and De Ruyter, A. (2010) 'The MG Rover closure and the policy response: An evaluation of the task force model in the UK', Int. J. Automotive Technology and Management, Vol. $X$, No. X, pp XX -XX..

Biographical notes: Gill Bentley is a Lecturer and Research Consultant in Urban and Regional Economic Development at the University of Birmingham in the UK. Her principal research interests include industrial and regional policy, industry clusters, and the automotive and food industries. Recent work has included the evaluation of Accelerate, the industry support programme for firms in the automotive industry supply chain. She was a co-investigator on the Economic and Social Research Council funded project investigating the impact of the MG Rover closure in Birmingham and the policy response to this.

David Bailey is Professor of International Business Strategy and Economics at Coventry University Business School, UK. He has written extensively on industrial and regional policy and globalisation, especially in relation to the auto industry. $\mathrm{He}$ was principal investigator on an Economic and Social Research Council (ESRC) project looking at the impact of the MG Rover closure and the policy response to this. Bailey has held visiting posts In Italy, the US, France and the Czech Republic. Outside of Coventry University, David is Chair of the Regional Studies Association.

Alex de Ruyter is Professor of Public Sector Management at the University of the West of Scotland. He has written extensively on employment relations, labour markets and economic policy. He has been involved in a number of funded research projects, including two recent Economic and Social Research Council projects looking at agency work in the health and social care sectors, as well as the impact of the MG Rover closure in Birmingham and its impact on workers. 


\section{Introduction}

MG Rover closed in 2005 with the loss of 6,300 jobs. More jobs were lost in the supply chain. At first it was thought that as many as 12,000 jobs would be at risk but in the event the loss, estimated at 8,500 jobs, was less than initially expected (Bailey and Kobayashi, 2008). The UK government stepped in to deal with the closure and the MG Rover Task Force was set up to formulate the policy response. Task forces are not new; they have been common in the UK and elsewhere in bringing together multiple agencies to come up with solutions to tackle particular issues. Research on the nature and workings of task forces, especially on a comparative international basis is, however, limited.

The aim of this paper is to assess the MG Rover Task Force to explore the extent to which the Task Force displayed effective governance and was able to secure multi-level working, across territorial boundaries and tiers of government, and to devise a policy response tailored to people's needs in dealing with the immediate impacts of the closure [endnote 1]. Given contemporary debates in Britain over devolved responsibilities, a critical assessment on the ground is naturally important. Moreover, it can serve as one point of reference for future comparative research, drawing in the approaches and experience of other countries, in the EU and elsewhere in dealing with auto plant closures. These are significant economic events and are likely to continue given the over-capacity and restructuring taking place in the industry.

The paper is set out as follows. First it looks at the characteristics of a task force, and reviews the debate on devolved forms of governance, in order to establish criteria for the assessment of task forces. It next reviews the development of the MG Rover Task Force in 2005. This was the second task force to be set up to deal with employment issues at Rover, and the paper also looks at the work of the first Rover Task Force set up in 2000, when BMW divested itself of Rover. The paper then turns to an assessment of the MG Rover (MGR) Task Force.

It finds that the MGR Task Force displays characteristics of effective governance and it speedily yielded an extensive range of policies to support to those made redundant. However, as our research on the closure of MG Rover shows, while most workers took up the support offered, few ex-workers actually felt adequately supported by government or the local community (Bailey, Chapain, Mahdon and Fauth, 2008). This suggests that while the Task Force was successful in enabling a policy response to be developed, it was less successful in terms of gaining legitimacy for the actions taken as a result of its deliberations.

The paper concludes by suggesting that a key lesson is the need for policy responses to redundancy situations to be more responsive and that there is a need to gain legitimacy by communicating better with those being made redundant. This can help in both softening the blow of job loss and offer the hope that there has been a real attempt to develop a responsive policy to deal with the situation. Further research (and on a comparative basis) on the role of task forces in arriving at a policy response to auto industry closures is required and is especially relevant in the current economic crisis in 2009 when there are increasing redundancies. 


\section{Characteristics of a Task Force}

\subsection{Task Forces are not new}

There is some debate in the literature about the characteristics of a task force. There is clearly a military connotation to the term 'task force'; they emphasise the need for a rapid response to a crisis situation, of which there are a number of examples at national and international levels which have been set up to deal with natural and man made disasters. Task forces have however been more commonly set up to work on a single defined task or activity in a time limited way (i.e. a 'task and finish' group). These can be seen in the US in business practice but more particularly in the area of public policy. There is however a very limited literature on their use in the US, or in Europe; still less on their workings, which begs further and comparative research.

In the UK, however, task forces have been extensively used in a public policy context and especially in addressing problems of economic decline in urban areas. The UK may well be unique in such a reliance on the task force model. For Barker et al (1999: 11) they "investigate and recommend new policies and practices or... ...practical means of implementing policies". While definitional debate can be had they are, as Pike (2002: 723) points out, "different from routine and consultation exercises that are standard Civil Service work such as Royal Commissions, Departmental Committees of Inquiry, Standing Expert Advisory Committees and Standing Statutory Advisory Boards.”

\subsection{Task Force as Governance}

Pike $(2001,2002,2005)$ has undertaken the most extensive review of British task forces, as well as studies of closure of firms. He found that no less than 295 task forces had been set up at the national level in the UK between 1997 and 1999, to address a multitude of policy design and implementation questions. Pike (2002) offers a typology of the aims of task forces and categorises them by their focus on employers, sectors and/or territories (see Table 1).

[table 1 goes here]

Employer-based task forces are focused on particular employers in the locality and among other issues seek to address redundancy situations. The MG Rover Task Force falls into this category. Sectoral task forces also cover redundancy issues but in relation to sectors rather than individual companies, and undertake the analysis of trends in a sector, with the aim of improving competitiveness. Area based task forces, on the other hand, are in his view concerned with strategic issues in the regeneration and economic development of a locality. Local, regional and national level authorities in the UK have taken the lead in setting up the task forces and include local councils, Regional Development Agencies, and government departments [endnote 2].

It is clear that task forces generally involve leadership provided by the state in policy formulation and implementation but with the participation of a number of actors both from inside and outside the state. They can be said to reflect the shift in reference in discourses from government to governance, defined as:

"the complex art of steering multiple agencies, institutions and systems which are both operationally autonomous from one another and structurally coupled through various forms of reciprocal 
interdependence.... Such 'quasi-government' has been functional to states to incorporate independent specialised expertise and to devolve responsibility but has raised concerns about co-ordination, transparency and accountability..."

(Jessop, 1997: 575)

\subsection{The State Modernisation Debate}

Why have task forces emerged? Pike (2002) provides an answer in situating the emergence of the task force approach within the state modernisation debate (see also Jones et. al., 2005). This suggests that new state forms are evolving under changing conditions for capital accumulation. It can be argued that three factors are driving these changes: globalisation; the dominant neo-liberal ideology; and the lack of faith in existing political institutions.

Firstly, one can point to globalisation, where national control is thought to be no longer possible, given capital is both internationalising and regionalising, and which is leading to the (alleged) hollowing out of the nation state (Hirst and Thompson, 1995). This approach points to both the establishment of supranational institutions (such as the European Union and Mercosur in South America) as well as sub-national regional institutions, both to regulate economic development. This is giving rise to a pattern of multi-level governance, with institutions interacting and operating at different spatial scales (Hooghe and Marks, 2003).

Second, Pike points to a dominant neo-liberal ideology in the western world, which promulgates a programme of deregulation, liberalisation, low taxation, and monetary controls, which in turn brings changes in the form and functions of the state in free market economies. In this vein, the so called 'Third Way' political economic project of the Labour Government since 1997 in the UK, which suggests there is a path between market mechanisms and the state, 'provides a guiding theoretical shell for state modernisation' (Pike, 2002; Giddens, 1998). Indeed, it has been argued that while the British state under Labour is centrist, it is a 'new centralism' in which government has been seen to decentralise and devolve power to the regions, and to the local level. An economic development function was passed to the Regional Development Agencies (RDAs) set up in England in 1999 and power devolved to Scotland via the Scottish Parliament and Wales, through the Welsh Assembly, both also established in 1999. Nonetheless, this 'new centralism' is a 'steering centralism', where "the state controls through plans, targets, default powers and financial controls" (Corry and Stoker, 2002). In the language of Jessop (2004), there may be a situation of meta-governance, where governance operates 'in the shadow of hierarchy'.

As a third point, it is possible to point to a lack of faith in existing political institutions on the part of the electorate, which is leading to the establishment of new forms of the state to empower people. In the UK, 'partnership working' has almost become the norm, in particular in economic development and regeneration. For the Labour Government in the UK, in particular, the emphasis has been on including interest groups ('stakeholders') in the policy making process and to achieve 'joinedup' approaches in dealing with 'cross-cutting' issues (Mawson, 1999; Bennett and Payne, 2000). In essence, however, there has been a search for institutional forms to reflect the need to secure community engagement, so as to gain legitimacy for government and public policy interventions. This focuses attention on the transformational aspect of partnership working, which stresses the benefit of coming together and learning from each other the limits of action but it also questions the degree of inclusivity (Mackintosh, 1992). The emergence of task forces generally and 
the MG Rover Task Force in particular can be seen in the light of these developments. We turn to look at the constitution of the two Rover Task Forces before undertaking the assessment of the MG Rover Task Force.

\section{The Rover Task Force}

Two task forces have been set up in the West Midlands region in the UK to deal with closures and redundancies at Rover, the Rover Task Force mark 1 (RTF1), and the MG Rover Task Force mark 2 (RTF2). The paper focuses on the second but first, however, we look at RFT1 before turning our attention to the second task force.

\subsection{Rover Task Force Mark 1}

The first Rover Task Force was set up in 2000 by Stephen Byers, who was then Secretary of State for Trade and Industry, at the time when BMW divested itself of most of Rover, and split the company up (Bentley, 2000). This involved the rationalisation of production and its relocation in the different Rover plants located in different parts of the UK. BMW retained the Oxford plant to produce the new Mini, which was originally based at Longbridge, in Birmingham in the West Midlands. Production of the Rover 75 model, then based at Oxford, was shifted from Oxford to Longbridge. Longbridge was then sold to a local consortium, the Phoenix Group, for a nominal $£ 10$ (Bailey, 2003). Land Rover was sold to Ford for $£ 1.8$ billion, along with Rover's design facility.

The Task Force, clearly in Pike's terms an employer based task force, led by the RDA, Advantage West Midlands (AWM) with the support of the Government Office of the West Midlands (GOWM), and the Chamber of Commerce, pressed for a credible package to support and develop the regional economy. This was focused on inter-linked themes of Modernisation (with funding of $£ 17$ million), Diversification (£19.7 million) and Regeneration (£22 million) (RTF, 2000). This is a slightly different focus from RTF2. Nonetheless, each has dealt with a crisis and possible closure of an auto industry employer.

The modernisation programme included a number of linked initiatives to improve the competitiveness (in this case productivity) of the cluster. Among these was the Accelerate programme, managed by a Team at the Chamber of Commerce, which was funded to create supplier networks to contribute to improving activities in firms [endnote 3]. The diversification programme aimed to help suppliers diversify away from Rover and to encourage the application of engineering skills in other industries such as medical and nano technologies. RTF 1 assisted with development costs, with the Small Business Service providing a diversification service. The regeneration programme as will be seen below was concerned with the development of the site.

Behind all this however was basically the cluster approach to economic development, being taken by the RDA and which had evolved over time since the RDA's initial Regional Innovation Strategy (RIS) which in turn was the starting point in developing the West Midlands Economic Strategy (WMES). The RDA was able to use the RTF1 to accelerate and legitimise the emerging cluster policy and to extend it further. Indeed, the RTF1 was an attempt to link cluster policies with spatial targeting via corridors of regeneration, given continued concern over Rover's prospects. The RTF1 Final Report identified three areas for an in-depth study of their growth potential as 'high-tech corridors'. Of relevance here is the development of a 'Central 
Technology Belt' (CTB) which was to tie in the University of Birmingham and its teaching hospital, to utilise part of the site of the (down-scaled) Rover Longbridge plant, to establish a new 'medipark', to develop a medical technology cluster (RTF, 2000). The situation in 2005 was rather different; the company had actually closed and the new task force had to pick up the pieces.

\subsection{MG Rover Task Force (RTF2)}

The background to the closure of MG Rover is well documented (Coffey, 2009; Bailey, Kobayashi and MacNeill, 2008; Bentley, 2007; HOC 2007; NAO, 2006; Holweg and Oliver, 2005). Almost as soon as the announcement was made in April 2005 that MG Rover was going into administration, AWM and the national government moved quickly to set up a new Rover Task Force (MG RTF2). In fact, there was a nascent RTF - a Joint Planning Group - set up by the DTI (Department of Trade and Industry) - that had been working discreetly in the background on a contingency plan to deal with the effects of a closure, as far back as December 2004 (HOC, 2007). The terms of reference of the task force were firstly, to advise the Secretary of State on the following:

- The implementation of the emergency package of support for MG Rover suppliers, the Longbridge workforce and the local community;

- Other national and regional actions as appropriate to address the outcomes of the closure of MG Rover.

Secondly, to advise Advantage West Midlands on:

- The progress of regional and local partners in delivering the whole of the emergency package;

- Changes to the West Midlands Regional Economic Strategy and implementation plan in the light of the closure of MG Rover.

An aid package eventually worth $£ 176$ million was made available firstly, to help suppliers to keep going and to diversify; secondly, to aid workers in finding new jobs; and thirdly, to support the broader community. The MG Rover Task Force was involved in the development of policy to address the situation. The question is to what extent was it successful? We next turn to assess the effectiveness of the MG Rover Task Force.

\section{Assessment of the MG Rover Task Force}

\subsection{Methodology: Exploring the Requirements for Effective Governance}

In order to answer the question to what extent did the MG Rover Task Force display effective governance, we assess the workings of the Task Force by considering the dimensions of governance required for effective task force performance. As the literature suggests, task forces involve multi-level working across territorial boundaries and tiers of government and vision, leadership, collaboration and community engagement (Jessop, 1997; Pike, 2002). While being given devolved responsibility to carry out the tasks, the 'new centrist thesis' suggests that this is likely 
to be mediated by national policy, funding regimes and the remits of the participating agencies. We can also expect that a task force would produce tailored policy outcomes that better meet people's needs and that high quality services would be delivered. Lastly, their legitimacy needs to be apparent if they are to have a role in relation to crisis management. We assess the workings of the MG Rover Task Force from these perspectives.

\subsubsection{Empirical Work}

Our empirical work was carried out as of a research project undertaken over the period 2008-2009, funded by the Economic and Social Research Council (ESRC) in the UK, to look at the impact of the closure of MG Rover and the policy response, three years on from the closure. It included:

- A review of documents, reports and papers on the closure of MG Rover and the public policy response to the closure;

- A questionnaire survey of a representative sample of 204 ex MG Rover workers;

- Detailed face-to-face and telephone interviews with 30 ex MG Rover workers;

- In depth face-to face interviews with members of the Rover Task Force, national and local policy-makers and policy delivery agencies;

- In depth face-to-face interviews with community activists, and trade union officials.

We turn to explore the characteristics of the Task Force in terms of: the extent of multi-level working; the degree of devolved responsibility; the policy responses devised as a result of its deliberations, and the extent of the received legitimacy of the outcomes of the actions of the Task Force.

\subsection{Multi-Level Working?}

Looking at the constitution of the Task Force, it is clear that there was multi-level and multi-agency working. Members were from a spread of territories, tiers of government and other agencies and included:

- The national level (The DTI and local Members of Parliament (MPs));

- The regional level (such as the RDA);

- Local Authorities (among these, Birmingham City Council);

- Skills Agencies (such as the Learning and Skills Council);

- Employer organisations;

- Employers (GKN, and Hadley Industries);

- Trade Unions (for example, TGWU);

- Universities [endnote 4]

An interview with one of the local MPs confirmed that "sectoral partners worked together well" and that there was collaborative working among the partners, with leadership being taken by the RDA, Advantage West Midlands; "we had the right people around the table meeting on a regular basis to sort out any problems that came up".

However, membership was not completely inclusive. Some of the policy implementation agencies such as JobCentre Plus (JCP), the key government 
employment agency responsible for helping people find jobs, did not sit on the Task Force but was on the 'operational group', set up to support the work of the Task Force, instead. DWP (Department for Work and Pensions) were members of the Joint Planning Group, but were not members of the MGR Task Force. HM Revenue and Customs also did not appear to formally participate in the Task Force.

Community engagement is an important aspect of a Task Force. Our research revealed that there was community engagement, but that community organisations did not sit on the Task Force. However, the Task Force took advice (and acted on that advice) from community organisations. The Rover Community Action Trust was significant in this respect. A community organisation, which was set up by the partners of the Rover workers, were consulted and indeed was vociferous on what needed to be done to help those made redundant. Interviews revealed that some critical interventions were instituted after issues were raised by this group, such as the need to extend and refinance car loans so that ex-workers could remain mobile and hence look for work. A Constituency Strategic Partnership, (a local authority organisation), and a 'Community Support Board', made up of local agencies, were later set up to look at neighbourhood impacts and the policy response at the local scale, including the longer term regeneration of the Longbridge and Northfield areas, where the MG Rover factory was located.

\subsection{Devolved Responsibility?}

In respect of the degree of devolved responsibility, we find that in many ways the MG Rover Task Force exemplified a case of devolved responsibility. Although the Department of Trade and Industry took the lead in drawing up a contingency plan and in setting up the joint planning group in December 2004 to determine the government response to a possible closure situation (HOC, 2007), the DTI then handed over responsibility for dealing with the policy response to the closure down to the regional level. However, whilst the Task Force took decisions, it also referred up to Ministers and did not have an executive role as such. The Regional Development Agency AWM - in its leadership role - coordinated the 'multiple agencies... which [were] operationally autonomous... and structurally coupled' and which took action to deal with the impacts of the closure (MG RTF 2005, 2006). These included Task Force member agencies as well as those on the 'Executive Steering Group for Operational Activity', such as JobCentre Plus and the Learning and Skills Council (LSC), Birmingham City Council, the Government Office and the Chamber of Commerce (AWM, 2005). Our Interviews with policy makers and implementation agencies indicated that JobCentre Plus worked together with the Learning and Skills Council and that the latter liaised with local colleges over training courses.

The Task Force drew on expertise in the industry including Accelerate, as noted above, based at the Birmingham Chamber of Commerce, to determine what help firms in the automotive supply chain could be given, as well as from community organisations regarding the help that the workforce needed. Drawing on work done prior to the closure, the Task Force agreed policy and devised a package of measures. There is some evidence of the 'new centrism', however, in how central government made funding available. Initially some $£ 156 \mathrm{~m}$ was made available by the (then) Department of Trade and Industry. It was later increased to $£ 176 \mathrm{~m}$ through additional contributions of $£ 10$ million from Advantage West Midlands and $£ 10$ million from Birmingham City Council (NAO, 2006). The latter funding was allocated to support for the local community, such as debt advice. Support for community resources was limited, however; Birmingham City Council had to draw on European Social Funding 
for local initiatives. Thus there is evidence that the remit of the agency shapes the course of action adopted, with each agency having its role in the process, and that government puts in place controls over how the expenditure should be used (see Table 2).

[table 2 goes here]

\subsection{Tailored Policy Outcomes?}

In looking at the policy responses, it was clear that a considerable amount of work was put in to devising suitable responses to the closure, both prior to the closure and by the MGR Task Force. The DTI had commissioned two studies by the consultancy firm Regeneris Consulting (2005a, 2005b) to explore the likely impacts of the closure as a prelude to determining the policy response. Our study was principally concerned with the help given to the workers, but here we can consider what help was given to MGR suppliers to adjust to a markedly changed business environment.

Help for businesses included: the writing of revised strategy and business plans; specialist Business Advice Service; help with finding new business and developing new products; a training and a wage replacement package; and deferral of tax payments (through HM Revenue and Customs) (MG RTF, 2005; NAO, 2006). Accelerate offered support to firms in the automotive industry supply chain. AWM also set up the Advantage Transition Bridge Fund which offered loans of $£ 50,000$ and up to a maximum of $£ 500,000$ to businesses facing financial difficulty and having a viable recovery plan but insufficient finance from normal sources (NAO, 2006). The latter has been reactivated during the current recession, with $£ 9$ million being made available to support firms in the West Midlands, making this an example of how experience gained during the MGR Task Force can be reapplied.

Ex-workers received help with claiming benefits and finding a job and an information pack was given out. To meet an undertaking to ministers, JobCentre Plus registered at least 5,300 ex MGR workers in 7 days to qualify for benefits. They took on 160 extra staff and worked a double shift to do so at the main office near Longbridge (NAO, 2006 and interviews with JCP personnel). Redundancy payments were made by the Redundancy Payments Directorate of the DTI sooner than usual; the Human Resources Division of MGR was kept on until December 2005 to assist with this work (NAO, 2006). Pensions were safeguarded through the newly created Pension Protection Fund. JobCentre Plus worked with the Learning and Skills Council to deliver training opportunities, which included free travel and a training allowance to those made redundant. There was also help for partners and spouses of the ex workers as well. A skills and training needs analysis was offered to them. This was innovative; even more innovative was the relaxation of the so called ' 16 hour rule' on benefits and training, so that ex-workers could attend training courses without losing benefits (NAO, 2006: p50).

Other initiatives included a Jobs Fair, which was held in May 2005 and was attended by 140 employers, and a telephone 'hot line' which was established for people to call to ask for advice and help (NAO, 2006: p46). A special scheme - the 'Manufacturing Hub' - was also set up to enable those who wanted to find jobs in manufacturing firms. Companies employing ex -MG Rover workers were given an allowance for free retraining for each worker recruited, free retraining for existing employees and an induction support allowance of $£ 50$ per week. 
The question is how far this was really tailored to people's needs? The in depth interviews carried out with ex-workers revealed some criticisms of the help given, in particular, the insensitivity of case workers. There also was some criticism of the lack of availability of training schemes (Ipsos MORI, 2006). However, it must be noted that local colleges put on extra courses over the summer for ex-MG Rover workers and their spouses. The interviews with ex-workers and policy implementation agencies also revealed that there was confusion about what training allowances people were eligible for, and the number of courses that they could obtain funding for. Interviewees said that training courses led to jobs that they subsequently found they did not like or want to do. They wanted to take another training course to enable them to apply for a different job. However, funding was not always made available for them to do this. People also said they wanted counselling. Job loss is somewhat like bereavement; people needed help with adjusting not only to the loss of a job but, as our interviews with ex-workers found, with adjusting to a life changing experience (Chapain et al, 2008).

\subsection{Legitimacy}

As noted above, task forces are in part set up because it is hoped that the policy outcomes, in satisfying the polity, would give legitimacy to government action, and that this would be recognised as such and would thus afford electoral advantage. Indeed in the case of MG Rover, it can be argued that the British government wanted to be seen to doing something about the impact of the closure by setting up the MGR Task Force because of the political sensitivity of the closure both because of its iconic status and also because of timing - during the 2005 General Election. At the same time there are questions as to whether the government could have done more to avoid the closure occurring (Bailey and Kobayashi, 2008). From this point of view is it politically important that people recognise what Government is doing and that the policy response meets people's expectations. In discussions over the closure in 2009 of LDV, the Birmingham van maker, a number of workers were heard to express their frustrations, because the government did not step in with a financial rescue package to save LDV. Thus recognition of the legitimacy of action taken by government is important in relation to crisis management.

In respect of the reaction to measures undertaken by the MG Rover Task Force, we find both significant successes and also some cause for concern. Our survey of ex workers shows that three years on from the closure some $90 \%$ of the ex-workers had found jobs, with $56 \%$ visiting the jobs fair, and that $60 \%$ had taken up education or retraining. However, while many were happy in their new job, pay is on average $£ 5600$ less per year in real terms than what the workers received at MGR (Bailey, Chapain, Mahdon and Fauth, 2008). We also found that few workers viewed the jobs fair a useful form of help. Also, while $80 \%$ of respondents found free travel and $65 \%$ a free place on a training course were the most useful forms of help, take up of these forms of assistance was low, at $10 \%$ and $37 \%$. Indeed, despite all the help on offer to the ex-workers in finding another job, $70 \%$ said they found a new job through their own initiative or through personal contacts rather than via formal channels. In particular, our survey found that while most ex-workers $(75 \%)$ felt supported by family, friends and existing support networks; very few said they felt adequately supported by government $(6 \%)$ or their local community $(10 \%)$. This suggests that that despite all of its good work, the Task Force failed to gain legitimacy for its actions and to communicate to ex-workers the measures that it was undertaking, or to effectively manage expectations. 


\subsection{Lessons Learned}

Lessons have been learned from the closure of MG Rover. For example, local agencies, notably the Learning and Skills Council and Jobcentre Plus, devised a 'West Midlands Regional Redundancy Response Strategy and Implementation Framework'. This proposes that: skills brokers should be used to advise on job and training opportunities; that the public sector should take the lead management role; and that a provider network should be set up. In addition it recommends that employers should be offered services prior to the closure to help workers and that those being made redundant should be offered practical help and guidance. The strategy suggests that it should be based on partnership working and that the public and private sector should work together to develop high quality interventions in establishing a provider network to work responsively.

The findings of our research suggest that there is a need to let people know and understand better what help is available. Information was in fact available to those being made redundant. Information packs were given to those registering at the Job Centre. However it needs to be remembered that workers losing their jobs, especially on the scale and in the circumstances of the MG Rover closure, were in shock. They needed help in understanding the information. There is also a need to offer counselling to help people cope with redundancy, especially those experiencing depression and ill health as a result. While there was a speedy response to the crisis, interviews with ex-workers suggested that there is a need to be more sensitive to people who have never been unemployed and do not know how to make claims for benefit or search for a job. Additionally, better advice was needed on the entitlement to training courses, since there was confusion over this. There is also a need to inform people of the changed nature of the job market and the types of job that are likely to be available. In short, there is a need to manage expectations.

\section{Conclusions}

Since assuming power in 1997, the Labour government has used a number of task forces to deal with a variety of economic development issues. Their emergence can be explained by reference to the state modernisation thesis which points to the reorganisation of state structures at the central, regional and local level. Alongside this, there is the establishment of other less formal political institutions - including task forces - signifying a shift to governance, which include interest groups ('stakeholders') in the policy making process and 'joined up working' simply because issues are far too complex to be tackled by a single agency and because there is a search for legitimacy for government action.

Our research findings suggest that the MG Rover Task was largely successful in displaying effective governance. There was clear evidence of multi-agency and multilevel working. However, it was not necessarily inclusive, in that community groups were not part of the Task Force. However, it drew on their expertise and took advice from them. Responsibility was devolved to the Task Force, leadership being taken by the RDA, and various agencies were pulled in to deal with the impact of the closure, Deliberations in the Task Force saw innovative policy solutions being tailored to help both firms in the supply chain and those made redundant (MG RTF 2005, 2006). However, we suggest that the Task Force failed in one important respect, in terms of gaining legitimacy for its role. Despite the wide range of help available, take up was variable. More significantly, few ex-workers felt adequately supported by government. 
There was also some criticism of policy actions. From this point of view, the Task Force perhaps failed to gain legitimacy for its role and the recognition for the real work that it actually undertook.

This suggests that the transformative nature of partnership working embodied in the task force approach needs to be remembered. Task forces provide a mechanism for bringing agencies and groups together to synergise and produce innovative policy solutions. In future, it would be appropriate for task forces to look at ways of tackling the issue of making people aware of what is being done and for the messages to be transmitted.

A number of lessons learned have been picked up by the West Midlands Regional Task Force which has been newly set up and is looking at ways of mitigating the impacts of the current recession. In this sense there is an attempt to address the need for proactive and 'intelligent reactive' policies to become a 'permanent capacity' in order for policymakers to address large-scale redundancies as Bailey, Chapain, Mahdon and Fauth (2008) argue for (see also the House of Commons, 2009). Moreover, the Learning and Skills Council formulated a 'Regional Redundancy Response Strategy and Implementation Framework'. The LDV Task Force has been set up to deal with the latest large scale closure in the West Midlands, and the Advantage Transition Bridge Fund has been reactivated during the current recession, with $£ 9$ million being available to firms in the region.

We have also noted that the whilst task force may be a peculiarly British approach to dealing with redundancy situations, it would be useful for further and comparative research to explore any differences and similarities in their mode of operation, and more generally in terms of policy responses to plant closures. It also remains to be seen whether politically the actions being taken in the West Midlands in the UK meet people's expectations and whether they achieve successful crisis management.

\section{Acknowledgement}

The authors wish to acknowledge the support of the ESRC under award number RES000-22-2478. For more detail on the MG Rover case study, see Bailey, Chapain, Mahdon and Fauth (2008).

\section{References}

Amin, A. and Thrift, N.J. (1994) 'Living in the global', in A. Amin and N. Thrift (Eds.) Globalization, Institutions and Regional Development in Europe, Oxford: Oxford University Press, pp. 1-22.

Bailey, D. (2003) 'Globalisation, Regions and Cluster Policies: The Case of the Rover Task Force', Policy Studies, Vol. 24, Issue $2 \& 3$, pp. 67-85.

Bailey, D., Chapain, C., Mahdon, M. and Fauth, R. (2008) Life after Longbridge: Three Years on. Pathways to re-employment in a restructuring economy, London: The Work Foundation.

Bailey, D. and Kobayashi, S. (2008) Life After Longbridge? Crisis and Restructuring in the West Midlands Auto Cluster, in M. Farschi, O.Janne and P. McCann (Eds.), Industrial Regeneration and Regional Policy Options in a Global Economy, Cheltenham: Edward Elgar. 
Bailey, D., Kobayashi, S. and MacNeill, S. (2008) 'Rover and out? Globalisation, the West Midlands auto cluster, and the end of MG Rover', Policy Studies, Vol. 29, No. 3, pp. $267-279$.

Barker, T., Byrne, I, and Veall, A. (1999) Ruling by Task Force, London: Politico's/Democratic Audit.

Bentley, G. (2000) 'The Automotive Industry: Change and Challenge for the RDAs', in G. Bentley and J. Gibney (Eds.), Regional Development Agencies and Business Change, Aldershot: Ashgate.

Bentley, G. (2007) 'Dealing with strategic change: a trio of automotive industry closures in the West Midlands', Strategic Change, Vol.16, No. 8, pp. 361-370.

Bennett, R. Payne, D. (2000) Local and Regional Economic Development: Negotiating Power Under Labour, Ashgate: Aldershot.

Chapain, C., Bentley, G., Hall, S., Lee, P., Liu, X. and Murie, A. (2008) The Social Impact of the Closure of the Rover Plant at Longbridge and the Efficiency of the Policy Responses. Community Step Forward (MGR Task Force) Project, Birmingham: School of Public Policy, Centre for Urban and Regional Studies. The University of Birmingham.

Coffey, D. (2009) 'Production Counterfeit and Policy Collision: BMW and Rover - a salutary tale' in M. Freyssenet (Ed.) The New Automobile World in the 21st Century, Basingstoke and New York: Palgrave MacMillan.

Corry, D. and Stoker, G. (2002) New Localism: refashioning the centre-local relationship, London: New Local Government Network.

Giddens, A. (1998) The Third Way, Cambridge: Polity Press.

Hirst, P. and Thompson, G. (1995) 'Globalisation and the Future of the Nation State' Economy and Society, Vol. 24, No. 3, pp. 408-442.

Holweg, M. and Oliver, N. (2005) Who Killed MG Rover A Special Report from the Cambridge-MIT Institute Centre, Cambridge: Cambridge University.

Hooghe, L. and Marks, G. (2003) 'Unraveling the Central State, but How? Types of Multi-level Governance', American Political Science Review, Vol. 97, No. 2, pp. 233-243.

House of Commons (2007) Select Committee on Trade and Industry: Fourth Report, London: The Stationery Office.

House of Commons (2009) Select Committee on the West Midlands. The impact of the current economic and financial situation on businesses in the West Midlands Region. HC409. London: The Stationery Office.

Ipsos MORI (2006) The Closure of MG Rover: Perspectives of 38 former employees on the support provided by public agencies, London: MORI.

Jessop, B. (1997) 'Capitalism and its future: remarks on regulation, government and governance', Review of International Political Economy, Vol. 4, No. 3, pp. 561-581.

Jessop, B. (2004) 'Multi-level Governance and Multi-level Metagovernance', in I. Bache and M. Flinders (Eds.), Multi-Level Governance, Oxford: Oxford University Press.

Jones, R., Jones, M. and Goodwin, M. (2005) 'State Modernisation, Devolution and Economic Governance: An Introduction and Guide to Debate', Regional Studies, Vol. 39, No. 4, pp. 397-403.

Mackintosh, M. (1992) 'Partnership: Issues of Policy and Negotiation', Local Economy, Vol. 7, No. 3, pp. $210-224$. 
Mawson, J. (1999) Area Regeneration Policy - Management Problems, Paper for Institutional Capacity, Social Capital and Urban Governance Seminar, The County Thistle Hotel, Newcastle Upon Tyne, 15-16 April.

MG Rover Task Force (MG RTF) (2005) Six Months On. Prepared for submission to the Department of Trade and Industry, Birmingham: Advantage West Midlands.

MG Rover Task Force (MG RTF) (2006) Final Update Report: The work goes on Prepared for submission to the Department of Trade and Industry, Birmingham: Advantage West Midlands.

Mulgan, G. (2005) 'Joined up government: Past, present and future', in V. Bogdanor (Ed.), Joinedup government, Oxford: OUP/British Academy.

National Audit Office (NAO) (2006) The closure of MG Rover, Report by the Comptroller and Auditor General. Session 2005-06, HC 961, London: The Stationary Office.

Pearce, G. (2001) 'Multi-Level Governance: Constitutional Reform and British SubNational Government Engagement in Europe', Paper for the conference on Multi-Level Governance: Interdisciplinary Perspectives, University of Sheffield, 28-30th June.

Pike, A. (2001) 'Reflections on the Task Force Model in Economic Development' Local Economy, Vol. 16, No. 2, pp. 87-102.

Pike, A. (2002) 'Task forces and the organisation of economic development: the case of the North East region of England', Environment and Planning $C$ : Government and Policy, Vol. 20, No. 5, pp.717-739.

Pike, A. (2005) 'Building a geographical political economy of closure: the case of R\&DCo in North East England', Antipode, Vol. 39, No.1, pp. 93-125.

Regeneris Consulting (RC), MG Rover Task Force (2005a), Closure of MG Rover: economic impact assessment: An interim report.

Regeneris Consulting (RC), MG Rover Task Force (2005b) Closure of MG Rover: economic impact assessment. Stage 2 report.

Rover Task Force (RTF). (2000) Final Report and Recommendations to the Secretary of State for Trade and Industry. 


\section{Notes}

1. The research project, The Economic and Social Impact of the Demise of Rover at Longbridge: A Longitudinal and Holistic Approach to Economic Restructuring, funded by ESRC (award number RES-000-22-2478), looked at the impact of the closure of MG Rover on workers and the neighbourhood three years on as well as the policy response. It involved a survey of former workers.

2. These included UK government departments, namely, DTI (Department of Trade and Industry), now called BIS, (Department of Business, Innovation and Skills) and prior to this, BERR (Department of Business, Enterprise and Regulatory Reform) and also DETR, (Department of Environment, Transport and the Regions) now called DCLG - the Department of Communities and Local Government.

3. Accelerate was responsible for a set of schemes of assistance for firms in the automotive industry supply chain. See Accelerate. http://www.accelerate.uk.net/

4. In more detail these were, at national level (the DTI's Automotive Unit and Members of Parliament for several local constituencies); the regional level (GOWM, AWM (the Regional Development Agency), and the West Midlands Regional Assembly); the local level (West Midlands Local Government Association, Birmingham City Council, Worcestershire County Council, Sandwell Council, the Black Country Consortium, and Birmingham Forward); the Skills Agencies (the Regional Skills Partnership and Birmingham and Solihull Learning and Skills Council); employer organisations (the SMMT (Society of Motor Manufacturers and Traders), Industry Forum, the CBI (Confederation of British Industry), EEF (Engineering Employers Federation), the Chamber of Commerce, and the Federation of Small Businesses); employers(GKN, and Hadley Industries); the Trade Unions (TGWU (Transport and General Workers), AMICUS (created by merger of the Manufacturing, Science and Finance (MSF) union and the Amalgamated Engineering and Electrical Union (AEEU)), the TUC (Trades Union Congress); and local Universities (Aston University, the Warwick Manufacturing Group and the West Midlands Higher Education Association). 
Table 1: Task Force Aims by Type

\begin{tabular}{|l|l|l|}
\hline \multicolumn{1}{|c|}{ Employer based } & \multicolumn{1}{|c|}{ Sectoral } & \multicolumn{1}{c|}{ Area based } \\
\hline $\begin{array}{l}\text { - Redeploy and/or retrain } \\
\text { redundant workforce }\end{array}$ & $\begin{array}{l}\text { - Analyse sectoral/regional } \\
\text { situation }\end{array}$ & $\begin{array}{l}\text { - Focus attention on target area } \\
\text { problems and opportunities }\end{array}$ \\
$\begin{array}{l}\text { - Secure sale of facility } \\
\text { and/or site }\end{array}$ & $\begin{array}{l}\text { - Recommendations to } \\
\text { improve competitiveness } \\
\text { - Assess community and } \\
\text { supply chain impact }\end{array}$ & $\begin{array}{l}\text { and retain employment } \\
\text { and initiatives }\end{array}$ \\
& - Assist redundant workforce & $\begin{array}{l}\text { - Monitor and review progress } \\
\text { Improve co-ordination and } \\
\text { integration between agencies }\end{array}$ \\
& & \\
& & \\
\hline
\end{tabular}

Source: Pike (2002)

\section{Table 2: The Regional Support Package}

\begin{tabular}{|l|c|}
\hline Nature of support & fmillion \\
\hline 1. For former employees & \\
\hline Statutory Redundancy payments and compensation awards & 40 \\
\hline Training for workers made redundant at MG Rover and suppliers & 50 \\
\hline 2. Support to MG Rover suppliers and retailers & 42 \\
\hline Grant support to former MG Rover suppliers & 25 \\
\hline $\begin{array}{l}\text { Loan support for suppliers and retailers struggling to finance a viable } \\
\text { recovery plan }\end{array}$ & 9 \\
\hline $\begin{array}{l}\text { Investment in technology and innovation infrastructure in the three West } \\
\text { Midlands High Tech corridors }\end{array}$ & \\
\hline 3. Support for the community (Funded by Birmingham City Council) & 10 \\
\hline Measures to address community impact & $\mathbf{1 7 6}$ \\
\hline Total & \\
\hline
\end{tabular}

Source: HOC (2007) 